\title{
Effects of seed rates on the growth and yield of different sunflower varieties
}

\author{
Hidayat Ali Panhwar ${ }^{1}$, Ghulam Mustafa Laghari ${ }^{1}$, Arshad Ali Kaleri ${ }^{2}$, \\ Mukesh Kumar Soothar ${ }^{3 *}$, Ayaz Ali Panhwar ${ }^{3}$, Jagdesh Kumar Soothar ${ }^{1}$, \\ Muhammad Mukhtar Rajput ${ }^{3}$, Arshadullah Abro $^{3}$ and Jay Kumar \\ Soothar ${ }^{2}$ \\ 1. Department of Agronomy, Sindh Agriculture University Tandojam-Pakistan \\ 2. Department of Plant Breeding and Genetics, Sindh Agriculture University Tandojam-Pakistan \\ 3. Department of Soil Science, Sindh Agriculture University Tandojam-Pakistan \\ *Corresponding author's email: mukeshksootar@gmail.com
}

Citation

Hidayat Ali Panhwar, Ghulam Mustafa Laghari, Arshad Ali Kaleri, Mukesh Kumar Soothar, Ayaz Ali Panhwar, Jagdesh Kumar Soothar, Muhammad Mukhtar Rajput, Arshadullah Abro and Jay Kumar Soothar. Effects of seed rates on the growth and yield of different sunflower varieties. Pure and Applied Biology. Vol. 6, Issue 4, pp11891197. http://dx.doi.org/10.19045/bspab.2017.600127

\begin{tabular}{llll}
\hline \hline Received: 22/05/2017 & Revised: 23/08/2017 & Accepted: 11/09/2017 & Online First: 16/09/2017 \\
\hline
\end{tabular}

\section{Abstract}

The study was conducted at student's Experimental Farm, Department of Agronomy, Sindh Agriculture University Tandojam to evaluate growth and yield of sunflower varieties as affected by seed rates during 2015. The experiment was laid out three replicated randomized complete block design (RCBD) Factorial. The treatments included 03 seed rates and 03 sunflower varieties. Net plot size was used in the experiment $3 \mathrm{~m} \times 3 \mathrm{~m}=9 \mathrm{~m}^{2}$. The seed rates were kept as Factor $A\left(\mathrm{~S}_{1}=5 \mathrm{~kg}, \mathrm{~S}_{2}\right.$ $=7.5 \mathrm{~kg}$ and $\left.\mathrm{S}_{3}=10 \mathrm{~kg} \mathrm{ha}^{-1}\right)$ and varieties as Factor $\mathrm{B}\left(\mathrm{V}_{1}=\mathrm{HO}-1, \mathrm{~V}_{2}=\mathrm{NKS}-278\right.$ and $\mathrm{V}_{3}=$ Hysun 38 ). In the present study sunflower varieties tested with seed rates, showed maximum mean plant height $(125.33) \mathrm{cm}$, stem girth $(6.28) \mathrm{cm}$, seed weight head ${ }^{-1}$ (44.94) $\mathrm{g}$, seed index 1000 seed weight (69.89) $\mathrm{g}$, head diameter (33.37) and seeds head ${ }^{-1}(690)$ at the seed rate $5 \mathrm{~kg} \mathrm{ha}^{-1}$. Maximum mean seed yield $\mathrm{kg} \mathrm{ha}^{-1}$ (2276.8) and the maximum mean plant population $\mathrm{m}^{2}(14.89)$ were recorded at the seed rate $10 \mathrm{~kg} \mathrm{ha}^{-1}$. Whereas, minimum mean stem girth $\mathrm{cm}$ (5.96), head diameter $\mathrm{cm}(31.02)$, seeds head $^{-1}(610)$, seed weight head ${ }^{-1}$ (34.58), seed index 1000 seed weight $g(52.33)$ were recorded at the seed rate $10 \mathrm{~kg} \mathrm{ha}^{-1}$. And minimum mean seed yield $\mathrm{kg} \mathrm{ha}^{-1}$ (1836.7) and plant population $\mathrm{m}^{2}(7.22)$ were recorded at seed rate $5 \mathrm{~kg} \mathrm{ha}^{-1}$. In case of varieties maximum mean of plant population $\mathrm{m}^{2}$ (11.78), plant height $\mathrm{cm}$ (184.8), stem girth $\mathrm{cm}$ (7.83), Head diameter $\mathrm{cm}$ (37.28), seeds head ${ }^{-1}$ (1028), seed weight head ${ }^{-1} \mathrm{~g}(64.63)$, seed index 1000 seed weight $\mathrm{g}(63.78)$ and seed yield kg ha ${ }^{-1}$ (2061.7) were recorded in variety HO-1 whereas minimum mean of plant population $\mathrm{m}^{2}(10.22)$, plant height $\mathrm{cm}$ (89.41), stem girth $\mathrm{cm}$ (4.54), seeds head ${ }^{-1}$ (433), seed weight head ${ }^{-1} \mathrm{~g} \mathrm{(26.67),} \mathrm{seed}$ yield $\mathrm{kg} \mathrm{ha}^{-1}$ (1990) were recorded in variety Hysun-38 and minimum head diameter cm (27.11), Seed index 1000 seed weight g (59.00) were observed in the variety NKS-278.

Keywords: Growth; Yield; Seed rates

\section{Introduction}

Sunflower (Helianthus annuus L.) is known as the significant wellspring of eatable oil creation on the planet [1]. Sunflower seeds carry $25-48$ per cent oil and 20-27 per cent protein. Though sunflower oil carries the 
high rate of poly unsaturated fats $(60 \%)$, acknowledged generally in eating regimen to lessen cholesterol in blood and in order to avoids heart diseases [2]. Sunflower oil is very acceptable and carries the dissolved vitamins $A, D, E$ and $K$ that recycled in synthesizing of margarine and cake as dairy cattle feed [3]. Pakistan imports, its more than $80 \%$ edible oil for meeting the residential utilization all at the while 201213; as the regional edible oil generation rarely met $20 \%$ of the household request. Sunflower can possibly extend up the crevice in the middle of interest and supply of eatable oil and it is all around adjusted to agro-environmental states of Pakistan. The oil obtained from sunflower was 101 thousand tons which was $16.67 \%$ of the aggregate palatable oil creation locally [4]. The seed rate and plant population impacted the development qualities, for example, plant stature and stem distance across and the advancement rates. The harvest demonstrated a noteworthy resilience to dry season and the capacity to improve after times of high moisture stress. Populaces of 60,000 to 75,000 plants $\mathrm{ha}^{-1}$ at column spacing of 35 to $60 \mathrm{~cm}$ are prescribed for dry land creation [5]. The seed rates of sunflower going from 10.0 to $37.5 \mathrm{~kg} \mathrm{ha}^{-1}$. Seed rates of (10.0-15.0 and $27.5-37.5 \mathrm{~kg}$ ) gave better yields of 2.5-6.5 g, linked and 10.0-11.8 $\mathrm{g}$ from seeding rate at (17.5-25.0 $\mathrm{kg}$ ). Seed yield was very and emphatically associated with the quantity of units and mostly but pessimistic associated with the number of days to flowering or maturity and percentage flower drop [6]. The seeding rate in sunflower is affected by the dividing in the middle of lines and the separation between plants in succession. Entomb line dispersing had no noteworthy impact on yield and oil content. Higher seed rate did not demonstrate valuable while low thickness planting with $5 \mathrm{~kg} \mathrm{ha}^{-1}$ seed rate brought about ideal results [7]. The seed rate is a critical element to impact crop administration components and yields, mostly low plant populaces can diminish product by lessening seed yield and oil focus and vast heads, from low plant populace, may oblige longer to dry down and hard to gather [8]. The large portion of the development and yield contributing characteristics are all together and emphatically corresponded with the plant populace in sunflower [9]. Seeding rate can be the 15,000 to 25,000 plants for every section of land. Sunflower does not yield better in limited columns, while wide lines are ideal for developing [10]. The impact of cultivars and seed rates on yield and yield parts of sunflower. Column dispersing had no noteworthy impact on grain yield under either arrangement of creation [11]. Plant separating essentially influenced all evaluated character and plant dividing of $22.5 \mathrm{~cm}$ was seen as a suitable plant thickness for acquiring the most extreme achene's yield (1920 kg ha-1), whereas lower plant spacing $(17.5 \mathrm{~cm}$ and $20 \mathrm{~cm})$ resulted less yield [12]. The suitable harvest stand assumes a critical part to produce fancied product yields in sunflower and legitimate seed rate results in a decent yield stand. The seeding rates and target populaces in sunflower may be up to between 50,00065,000 plants $\mathrm{ha}^{-1}$. There are suggestions that higher dampness conditions might permit excessive sunflower seeding rates, which in turn could enhance seed and oil yields [13]. The sunflower can be grown at the seeding rate of $2-3 \mathrm{~kg} \mathrm{acre}^{-1}$, however this is relying upon the hybrid varieties, soil sort, accessibility of water and strategy for sowing. The seed rate of hybrid varieties with vast seed size ought to be much when contrasted with little size seeds. In watered ranges more seed ought to be utilized contrasted with downpour bolstered territories. Seed rate is diminished to $50 \%$ if planted with new grower. For the most part 
the execution of sunflower yield is better when it is dispersed at $60-75 \mathrm{~cm}$ separation. Plant populace ought to be between 35,000 to 55,000 plants ha $^{-1}$ with change made for soil sort and yield potential. Lower populaces are prescribed for lighter soils, soils with the less water retaining capacity and if precipitation is conflicting and deficient [14]. The seed rate has critical impact on the sunflower seed yield; and the positive effect because of seeding rate. The effect of seeding rate on plant stand attributes demonstrated that there was no checked impact of seed rate on plant stature, however head width fluctuate by seeding rate with the largest seed heads $(15 \mathrm{~cm})$ at the most reduced seeding rate $(45,000$ plants $\left.\mathrm{ha}^{-1}\right)$. The littlest head width $(11.25 \mathrm{~cm})$ was in the most thickly seeded plots of 80,000 plants ha ${ }^{-1}[15]$.

\section{Material and methods}

The study was carried out at Students' experimental farm, Department of Agronomy, Sindh Agriculture University Tando jam to evaluate growth and yield of sunflower varieties as affected by seed rates. The treatments included 03 seed rates and 03 sunflower varieties. The plot size was used in the experiment $3 \mathrm{~m} \times 3 \mathrm{~m}\left(9 \mathrm{~m}^{2}\right)$. Randomized complete block design Factorial was to in experiment with three replications. Factor A consisted of 3 Seed Rates as; $\mathrm{S}_{1}=5 \mathrm{~kg} \mathrm{ha}^{-1} \mathrm{~S}_{2}=7.5 \mathrm{~kg} \mathrm{ha}^{-1}, \mathrm{~S}_{3}=$ $10 \mathrm{~kg} \mathrm{ha}^{-1}$ and Factor-B consisted of 3 varieties; $\mathrm{V}_{1}=\mathrm{HO}-1, \mathrm{~V}_{2}=\mathrm{NKS}-278$ and V3= Hysun -38

Treatment combinations

$\mathrm{T}_{1}=\mathrm{S}_{1} \mathrm{~V}, \quad \mathrm{~T}_{2}=\mathrm{S}_{1} \mathrm{~V}_{2}, \quad \mathrm{~T}_{3}=\mathrm{S}_{1} \mathrm{~V}_{3}, \quad \mathrm{~T}_{4}=\mathrm{S}_{2} \mathrm{~V}_{1}$, $\mathrm{T}_{5}=\mathrm{S}_{2} \mathrm{~V}_{2}, \mathrm{~T}_{6}=\mathrm{S}_{2} \mathrm{~V}_{3} \mathrm{~T}_{7}=\mathrm{S}_{3} \mathrm{~V}$

$\mathrm{T}_{8}=\mathrm{S}_{3} \mathrm{~V}_{2} \quad \mathrm{~T}_{9}=\mathrm{S}_{3} \mathrm{~V}_{3}$

\section{Data analysis}

The data was statistically analyzed through the MSTAT-C software; mean comparison was done using Duncan Multiple Comparison at 5\% probability level (Gomez and Gomez, 1984).

\section{Results}

\section{Plant population $\left(\mathrm{m}^{2}\right)$}

The result for plant population $\mathrm{m}^{2}$ of sunflower varieties significant for seed rates, varieties and their interaction presented in Table 1 and their analysis for variance is presented in appendix - I.

The Table result showed that the maximum mean plant population $\mathrm{m}^{2}$ was recorded (14.89) at seed rate $10 \mathrm{~kg} \mathrm{ha}^{-1}$ whereas the minimum mean plant population $\mathrm{m}^{2}$ (7.22) was observed at $5 \mathrm{~kg} \mathrm{ha}^{-1}$. In varieties the maximum mean plant population $\mathrm{m}^{2}(11.78)$ was observed in variety Ho-1 and minimum plant population (10.22) $\mathrm{m}^{2}$ was recorded in variety Hysun 38. The interaction results showed the maximum plant population $\mathrm{m}^{2}$ (15.67) at interaction of seed rate $10 \mathrm{~kg} \mathrm{ha}^{-1}$ $\mathrm{x}$ variety Ho- 1 whereas the minimum plant population (7.00) plants $\mathrm{m}^{2}$ at the seed rate 5 $\mathrm{kg} \mathrm{ha}^{-1} \mathrm{x}$ varieties NKS-278 and Hysun-38.

Table 1. Plant population $\left(\mathrm{m}^{2}\right)$ of different sunflower varieties as affected by various seed rates

\begin{tabular}{|l|c|c|c|c|}
\hline \multirow{2}{*}{ Seed rates $\left(\mathbf{k g ~ h a}^{-1}\right)$} & \multicolumn{3}{|c|}{ Varieties } & \multirow{2}{*}{ Mean for seed rates } \\
\cline { 2 - 4 } & Ho-1 & NKS-278 & Hysun-38 & \\
\hline $5 \mathrm{~kg} \mathrm{ha}^{-1}$ & $7.67 \mathrm{~g}$ & $7.00 \mathrm{~h}$ & $7.00 \mathrm{~h}$ & $7.22 \mathrm{C}$ \\
\hline $7.5 \mathrm{~kg} \mathrm{ha}^{-1}$ & $12.00 \mathrm{~d}$ & $9.67 \mathrm{f}$ & $11.00 \mathrm{e}$ & $10.89 \mathrm{~B}$ \\
\hline $10 \mathrm{~kg} \mathrm{ha}^{-1}$ & $15.67 \mathrm{a}$ & $14.00 \mathrm{c}$ & $15.00 \mathrm{~b}$ & $14.89 \mathrm{~A}$ \\
\hline Mean for varieties & $11.78 \mathrm{~A}$ & $10.22 \mathrm{C}$ & $11.00 \mathrm{~B}$ & \\
\hline
\end{tabular}




\section{Plant height (cm)}

The result for plant height $(\mathrm{cm})$ of sunflower varieties significant for seed rates, varieties and their interaction indicated in Table 2 and their analysis for variance is presented in appendix - II.

The Table result indicated the maximum mean plant height $(125.33) \mathrm{cm}$ at seed rate 5 $\mathrm{kg} \mathrm{ha}^{-1}$ whereas the minimum plant height (119.16) $\mathrm{cm}$ observed at seed rate $10 \mathrm{~kg} \mathrm{ha}^{-1}$.
In varieties the maximum mean plant height (184.8) was observed in variety Ho-1 and minimum plant height (89.41) $\mathrm{cm}$ was recorded in variety hysun-38. The interaction results showed the maximum plant height $(195.00) \mathrm{cm}$ at interaction of seed rate $5 \mathrm{~kg} \mathrm{ha}^{-1} \mathrm{x}$ variety Ho-1, whereas minimum interaction result was observed (73.67) $\mathrm{cm}$ at the seed rate $5 \mathrm{~kg} \mathrm{ha}^{-1} \mathrm{x}$ variety Hysun-38.

Table 2. Plant height $(\mathrm{cm})$ of different sunflower varieties as affected by various seed rates

\begin{tabular}{|l|c|c|c|c|}
\hline \multirow{2}{*}{ Seed Rates kg ha-1 } & \multicolumn{3}{|c|}{ Varieties } & \multirow{2}{*}{ Mean for seed rates } \\
\cline { 2 - 5 } & Ho-1 & NKS-278 & Hysun-38 & $125.33 \mathrm{~A}$ \\
\hline $5 \mathrm{~kg} \mathrm{ha}^{-1}$ & $195.00 \mathrm{a}$ & $107.33 \mathrm{~d}$ & $73.67 \mathrm{i}$ & $120.17 \mathrm{~B}$ \\
\hline $7.5 \mathrm{~kg} \mathrm{ha}^{-1}$ & $182.00 \mathrm{~b}$ & $85.95 \mathrm{~g}$ & $95.57 \mathrm{f}$ & $119.16 \mathrm{~B}$ \\
\hline $10 \mathrm{~kg} \mathrm{ha}^{-1}$ & $177.33 \mathrm{c}$ & $78.13 \mathrm{~h}$ & $102.00 \mathrm{e}$ & \\
\hline Mean for varieties & $184.8 \mathrm{~A}$ & $90.5 \mathrm{~B}$ & $89.41 \mathrm{~B}$ & \\
\hline
\end{tabular}

\section{Stem girth $(\mathbf{c m})$}

The result for plant height $(\mathrm{cm})$ of sunflower varieties significant for seed rates, varieties and their interaction presented in Table 3 and their analysis for variance is presented in appendix - III.

The Table result showed the maximum mean stem girth $\mathrm{cm}(6.28$ and 6.21$)$ at seed rates 5 and $7.5 \mathrm{~kg} \mathrm{ha}^{-1}$ whereas minimum mean stem girth (5.96) $\mathrm{cm}$ was observed at
$10 \mathrm{~kg} \mathrm{ha}^{-1}$. In varieties the maximum mean stem girth (7.83) $\mathrm{cm}$ were recorded in variety Ho-1 and the minimum mean stem girth $(4.54) \mathrm{cm}$ was recorded in variety Hysun-38. In case of interaction results showed that the maximum stem girth $\mathrm{cm}$ (8.33) at seed rate $5 \mathrm{~kg} \mathrm{ha}^{-1} \mathrm{x}$ variety Ho-1, whereas minimum interaction result were observed (4.33 and 4.63) $\mathrm{cm}$ at seed rates 10 $\mathrm{kg}$ and $7.5 \mathrm{~kg} \mathrm{ha}^{-1} \mathrm{x}$ variety Hysun-38.

Table 3. Stem girth of diferent sunflower varieties as affected by various seed rates

\begin{tabular}{|l|c|c|c|c|}
\hline \multirow{2}{*}{ Seed Rates kg ha-1 } & \multicolumn{3}{|c|}{ Varieties } & \multirow{2}{*}{ Mean for seed rates } \\
\cline { 2 - 4 } & Ho-1 & NKS-278 & Hysun-38 & $6.28 \mathrm{~A}$ \\
\hline $5 \mathrm{~kg} \mathrm{ha}^{-1}$ & $7.50 \mathrm{~b}$ & $6.67 \mathrm{c}$ & $4.67 \mathrm{de}$ & $6.21 \mathrm{AB}$ \\
\hline $7.5 \mathrm{~kg} \mathrm{ha}^{-1}$ & $7.67 \mathrm{~b}$ & $6.33 \mathrm{c}$ & $4.63 \mathrm{de}$ & $5.96 \mathrm{~B}$ \\
\hline $10 \mathrm{~kg} \mathrm{~h}^{-1}$ & $8.33 \mathrm{a}$ & $5.03 \mathrm{~d}$ & $4.33 \mathrm{e}$ & \\
\hline Mean for varieties & $7.83 \mathrm{~A}$ & $6.03 \mathrm{~B}$ & $4.54 \mathrm{C}$ & \\
\hline
\end{tabular}

\section{Head diameter $(\mathbf{c m})$}

The head diameter $(\mathrm{cm})$ result of sunflower varieties significant for seed rates, varieties and their interaction presented in Table 4 and their analysis for variance is presented in appendix - IV.

The Table results showed the maximum mean head diameter $\mathrm{cm}(33.3$ and $33.37 \mathrm{~cm})$ at seed rates 5 and $7.5 \mathrm{~kg} \mathrm{ha}^{-1}$ whereas minimum mean head diameter $(31.02) \mathrm{cm}$ was observed at $10 \mathrm{~kg} \mathrm{ha}^{-1}$.In varieties the maximum mean head diameter $\mathrm{cm}$ (37.28) was observed in variety Ho-1 and the minimum mean head diameter $\mathrm{cm}$ (27.11) was recorded in variety NKS- 278. The interaction results showed the maximum 
head diameter $(37.10,37.58$ and 37.00$) \mathrm{cm}$ at interaction of seed rates $5,7.5$ and $10 \mathrm{~kg}$ $\mathrm{ha}^{-1} \mathrm{x}$ variety Ho-1, whereas minimum interaction results were observed $(25.67) \mathrm{cm}$ at the seed rate $7.5 \mathrm{~kg} \mathrm{ha}^{-1} \mathrm{x}$ variety NKS278.

Table 4. Head diameter $(\mathrm{cm})$ of different sunflower varieties as affected by various seed rates

\begin{tabular}{|l|c|c|c|c|}
\hline \multirow{2}{*}{ Seed rates kg ha-1 } & \multicolumn{3}{|c|}{ Varieties } & \multirow{2}{*}{ Mean for seed rates } \\
\cline { 2 - 4 } & Ho-1 & NKS-278 & Hysun-38 & \\
\hline $5 \mathrm{~kg} \mathrm{ha}^{-1}$ & $37.10 \mathrm{a}$ & $28.00 \mathrm{~d}$ & $35.00 \mathrm{~b}$ & $33.37 \mathrm{~A}$ \\
\hline $7.5 \mathrm{~kg} \mathrm{ha}^{-1}$ & $37.58 \mathrm{a}$ & $27.67 \mathrm{~d}$ & $34.13 \mathrm{~b}$ & $33.13 \mathrm{AB}$ \\
\hline $10 \mathrm{~kg} \mathrm{ha}^{-1}$ & $37.00 \mathrm{a}$ & $25.67 \mathrm{e}$ & $30.40 \mathrm{c}$ & $31.02 \mathrm{~B}$ \\
\hline Mean for varieties & $37.28 \mathrm{~A}$ & $27.11 \mathrm{C}$ & $33.18 \mathrm{~B}$ & \\
\hline
\end{tabular}

\section{Seeds head ${ }^{-1}$}

The result for seeds head ${ }^{-1}$ of sunflower varieties significant for seed rates, varieties and their interaction shown in Table 5 and their analysis for variance is presented in appendix $-\mathrm{V}$.

The Table results revealed the maximum mean seeds head $^{-1}(690)$ seeds at seed rate 5 $\mathrm{kg} \mathrm{ha}^{-1}$ whereas minimum mean seeds head ${ }^{-1}$ (610) were observed at seed rate $10 \mathrm{~kg} \mathrm{ha}^{-1}$.
In varieties the maximum mean (1028) for seeds head ${ }^{-1}$ was observed in variety HO-1 and the minimum mean (433) seeds head ${ }^{-1}$ were recorded in variety Hysun-38. The interaction results showed the maximum (1149) seeds head ${ }^{-1}$ at the seed rate $5 \mathrm{~kg} \mathrm{ha}^{-1}$ $\mathrm{x}$ variety Ho-1, whereas minimum interaction result was observed (346) seeds head $^{-1}$ with the seed rates $7.5 \mathrm{~kg} \mathrm{ha}^{-1} . \mathrm{x}$ variety Hysun-38.

Table 5. Seeds head ${ }^{-1}$ of different sunflower varieties as affected by various seed rates

\begin{tabular}{|l|c|c|c|c|}
\hline \multirow{2}{*}{ Seed rates kg ha } & \multicolumn{3}{|c|}{ Varieties } & \multirow{2}{*}{ Mean for seed rates } \\
\cline { 2 - 4 } & Ho-1 & NKS-278 & Hysun-38 & \\
\hline $5 \mathrm{~kg} \mathrm{ha}^{-1}$ & $1149.7 \mathrm{a}$ & $405.0 \mathrm{~g}$ & $516.7 \mathrm{~d}$ & $690.44 \mathrm{~A}$ \\
\hline $7.5 \mathrm{~kg} \mathrm{ha}^{-1}$ & $998.3 \mathrm{~b}$ & $506.0 \mathrm{~d}$ & $346.7 \mathrm{~h}$ & $617.00 \mathrm{~B}$ \\
\hline $10 \mathrm{~kg} \mathrm{ha}^{-1}$ & $936.0 \mathrm{c}$ & $457.7 \mathrm{e}$ & $436.3 \mathrm{f}$ & $610.00 \mathrm{~B}$ \\
\hline Mean for varieties & $1028.0 \mathrm{~A}$ & $456.2 \mathrm{~B}$ & $433.2 \mathrm{C}$ & \\
\hline
\end{tabular}

\section{Seed weight head ${ }^{-1}(\mathrm{~g})$}

The result for seed weight head $^{-1}$ of sunflower varieties significant for seed rates, varieties and their interaction presented in Table 6 and their analysis for variance is presented in appendix - VI.

The Table results revealed the maximum mean seed weight head $^{-1}(44.94, \mathrm{~g})$ at seed rate $5 \mathrm{~kg} \mathrm{ha}^{-1}$ whereas minimum mean seed weight head $^{-1}$ (34.58) grams were observed at $10 \mathrm{~kg} \mathrm{ha}^{-1}$. In varieties the maximum mean for seed weight head ${ }^{-1}(64.63, \mathrm{~g})$ were observed in variety $\mathrm{HO}-1$ and minimum mean seed weight head ${ }^{-1}(26.67, \mathrm{~g})$ were recorded in variety Hysun-38. The interaction results showed the maximum seed weight head ${ }^{-1}(73.08, \mathrm{~g})$ were with the seed rate $5 \mathrm{~kg} \mathrm{ha}^{-1} \mathrm{x}$ variety Ho-1 whereas minimum interaction result seed weight head $^{-1}(21.33, \mathrm{~g})$ were observed at the seed rates $10 \mathrm{~kg} \mathrm{ha}^{-1} \mathrm{X}$ variety Hysun-38. 
Table 6. Seed weight head ${ }^{-1}(\mathrm{~g})$ of different sunflower varieties as affected by various seed rates

\begin{tabular}{|l|c|c|c|c|}
\hline \multirow{2}{*}{ Seed rates } & \multicolumn{3}{|c|}{ Varieties } & \multirow{2}{*}{ Mean for seed rates } \\
\cline { 2 - 4 } & Ho-1 & NKS-278 & Hysun-38 & \\
\hline $5 \mathrm{~kg} \mathrm{ha}^{-1}$ & $73.08 \mathrm{a}$ & $36.58 \mathrm{~d}$ & $25.17 \mathrm{~g}$ & $44.94 \mathrm{~A}$ \\
\hline $7.5 \mathrm{~kg} \mathrm{ha}^{-1}$ & $66.18 \mathrm{~b}$ & $24.47 \mathrm{~g}$ & $33.50 \mathrm{e}$ & $41.37 \mathrm{~B}$ \\
\hline $10 \mathrm{~kg} \mathrm{ha}^{-1}$ & $54.50 \mathrm{c}$ & $27.91 \mathrm{f}$ & $21.33 \mathrm{~h}$ & $34.58 \mathrm{C}$ \\
\hline Mean for varieties & $64.63 \mathrm{~A}$ & $29.66 \mathrm{~B}$ & $26.67 \mathrm{C}$ & \\
\hline
\end{tabular}

Seed index (1000 seed weight, $\mathrm{g})$

The result for seed index (1000 seed weight, g) of sunflower varieties significant for seed rates, varieties and their interaction presented in Table 7 and their analysis for variance is presented in appendix-VII.

The Table results showed the maximum mean seed index (1000 seed weight, g) $(69.89, \mathrm{~g})$ were at seed rate $5 \mathrm{~kg} \mathrm{ha}^{-1}$, whereas minimum mean seed index $(1000$ seed weight, g) $(52.33, \mathrm{~g})$ were observed at seed rate $10 \mathrm{~kg} \mathrm{ha}^{-1}$. In varieties the maximum mean for seed index (1000 seed weight, g) $(63.78, \mathrm{~g})$ were observed in varieties Ho-1, whereas the minimum mean seed index (1000 seed weight) (59.00) grams were recorded in variety NKS-278. The interaction results showed the maximum seed index (1000 seed weight, g) $(71.67, \mathrm{~g})$ at interaction of seed rate $5 \mathrm{~kg} \mathrm{ha}^{-}$ $1 \mathrm{x}$ varieties Ho-1, whereas minimum interaction result of seed index (1000 seed weight) was observed $(43.67, \mathrm{~g}$ ) at the seed rates $10 \mathrm{~kg} \mathrm{ha}^{-1} \mathrm{x}$ variety NKS-278.

Table 7. Seed index (1000 seed weight, g) of different sunflower varieties as affected by various seed rates

\begin{tabular}{|l|c|c|c|c|}
\hline \multirow{2}{*}{ Seed rates kg ha-1 } & \multicolumn{3}{|c|}{ Varieties } & \multirow{2}{*}{ Mean for seed rates } \\
\cline { 2 - 4 } & Ho-1 & NKS-278 & Hysun-38 & $69.89 \mathrm{~A}$ \\
\hline $5 \mathrm{Kg} \mathrm{ha}^{-1}$ & $71.67 \mathrm{a}$ & $70.00 \mathrm{a}$ & $68.00 \mathrm{a}$ & $61.78 \mathrm{~B}$ \\
\hline $7.5 \mathrm{Kg} \mathrm{ha}^{-1}$ & $59.33 \mathrm{ab}$ & $63.33 \mathrm{a}$ & $62.67 \mathrm{a}$ & $52.33 \mathrm{C}$ \\
\hline $10 \mathrm{Kg} \mathrm{ha}^{-1}$ & $60.33 \mathrm{ab}$ & $43.67 \mathrm{~b}$ & $53.00 \mathrm{ab}$ & \\
\hline Mean for varieties & $63.78 \mathrm{~A}$ & $59.00 \mathrm{~A}$ & $61.22 \mathrm{~A}$ & \\
\hline
\end{tabular}

Seed yield $\left(\mathrm{kg} \mathrm{ha}^{-1}\right)$

The result for seed yield $\left(\mathrm{kg} \mathrm{ha}^{-1}\right)$ of sunflower varieties significant for seed rates, varieties and their interaction presented in Table 8 and their analysis for variance is presented in appendix - VIII.

The Table results showed the maximum mean seed yield (2276.8) $\mathrm{kg} \mathrm{ha}^{-1}$ at seed rate $10 \mathrm{~kg} \mathrm{ha}^{-1}$, whereas minimum mean seed yield (1836.7) $\mathrm{kg} \mathrm{ha}^{-1}$ were observed at seed rate $5 \mathrm{~kg} \mathrm{ha}^{-1}$. In varieties the maximum mean seed yield (2061.7) $\mathrm{kg} \mathrm{ha}^{-1}$ was recorded in variety HO-1, whereas the minimum mean seed yield (1990) $\mathrm{kg} \mathrm{ha}^{-1}$ were observed in variety Hysun- 38 . The interaction results showed the maximum seed yield (2366) $\mathrm{kg} \mathrm{ha}^{-1}$ at interaction of seed rate $10 \mathrm{~kg} \mathrm{ha}^{-1} \mathrm{x}$ variety Ho-1, whereas minimum interaction result of seed yield (1725) $\mathrm{kg} \mathrm{ha}^{-1}$ were observed at the seed rate $5 \mathrm{~kg} \mathrm{ha}^{-1} \mathrm{x}$ variety Hysun- 38 . 
Table 8. Seed yield $\left(\mathrm{kg} \mathrm{ha}^{-1}\right)$ of different sunflower varieties as affected by various seed rates

\begin{tabular}{|l|c|c|c|c|}
\hline \multirow{2}{*}{ Seed rates kg ha-1 } & \multicolumn{3}{|c|}{ Varieties } & \multirow{2}{*}{ Mean for seed rates } \\
\cline { 2 - 4 } & Ho-1 & NKS-278 & Hysun-38 & \\
\hline $5 \mathrm{Kg} \mathrm{ha}^{-1}$ & $1859.3 \mathrm{e}$ & $1925.0 \mathrm{de}$ & $1725.7 \mathrm{f}$ & $1836.7 \mathrm{C}$ \\
\hline $7.5 \mathrm{Kg} \mathrm{ha}^{-1}$ & $1959.0 \mathrm{~d}$ & $1944.0 \mathrm{de}$ & $2059.3 \mathrm{c}$ & $1987.7 \mathrm{~B}$ \\
\hline $10 \mathrm{Kg} \mathrm{ha}^{-1}$ & $2366.7 \mathrm{a}$ & $2277.3 \mathrm{ab}$ & $2186.3 \mathrm{~b}$ & $2276.8 \mathrm{~A}$ \\
\hline Mean for varieties & $2061.7 \mathrm{~A}$ & $2048.8 \mathrm{~A}$ & $1990.4 \mathrm{~B}$ & \\
\hline
\end{tabular}

\section{Discussion}

Sunflower seeds differ in size, so seeding rate taking weight must consider into record seed size, however will be about 5 to $7 \mathrm{~kg}$ $\mathrm{ha}^{-1}$ [10]. The experiment results showed that the enhanced plant population $\mathrm{m}^{2}$ was recorded at seed rate $10 \mathrm{~kg} \mathrm{ha}^{-1}$ whereas the minimum plant population $\mathrm{m}^{2}$ was observed at $5 \mathrm{~kg} \mathrm{ha}^{-1}$. In varieties the maximum plant population $\mathrm{m}^{2}$ was observed in variety HO-1 and minimum plant population $\mathrm{m}^{2}$ was recorded in variety Hysun 38. The interaction results showed the maximum plant population $\mathrm{m}^{2}$ was recorded at interaction of seed rate $10 \mathrm{~kg} \mathrm{ha}^{-1} \mathrm{x}$ variety HO-1 whereas the minimum plant population $\mathrm{m}^{2}$ was found at the seed rate of 5 $\mathrm{kg} \mathrm{ha}^{-1} \mathrm{x}$ varieties NKS-278 and Hysun-38 and results regarding head diameter $\mathrm{cm}$ showed that the maximum head diameter $\mathrm{cm}$ was recorded at seed rates $5 \mathrm{~kg} \mathrm{ha}^{-1}$ whereas minimum head diameter $\mathrm{cm}$ was observed at $10 \mathrm{~kg} \mathrm{ha}^{-1}$.In varieties the maximum head diameter $\mathrm{cm}$ was observed in variety $\mathrm{HO}-1$ and the minimum mean head diameter $\mathrm{cm}$ was recorded in variety NKS- 278. The interaction results showed the maximum head diameter $\mathrm{cm}$ was recorded at interaction of seed rate $7.5 \mathrm{~kg} \mathrm{ha}^{-1} \mathrm{x}$ variety HO-1, whereas minimum interaction results were observed at the seed rate $5 \mathrm{~kg} \mathrm{ha}^{-1} \mathrm{x}$ variety NKS-278. Similarly [8] reported that seed rate is a critical component to impact crop administration variables and yields, Unnecessarily low plant populaces can lessen product esteem by decreasing seed yield and seed oil focus. The experiment result showed the maximum seed index (1000 seed weight, g) were observed at seed rate $5 \mathrm{~kg} \mathrm{ha}^{-1}$, whereas minimum seed index (1000 seed weight, g) was recorded at seed rate $10 \mathrm{~kg} \mathrm{ha}^{-1}$. In varieties the maximum seed index (1000 seed weight, g) were observed in varieties Ho-1, whereas the minimum mean seed index (1000 seed weight) were recorded in variety NKS-278. The interaction results showed the maximum seed index (1000 seed weight, g) was observed at interaction of seed rate $5 \mathrm{~kg}$ $\mathrm{ha}^{-1} \mathrm{x}$ varieties Ho-1 and NKS-278, whereas minimum interaction result of seed index (1000 seed weight) was observed at the seed rates $10 \mathrm{~kg} \mathrm{ha}^{-1} \mathrm{x}$ variety NKS-278. Similarly [14] built up a generation innovation that sunflower may be sown at the seeding rate of 2-3 kg acre ${ }^{-1}$, however this is relying upon cross breed, soil sort, accessibility of water and system for sowing. The seed rate of crossovers with substantial seed size ought to be more when contrasted with little size seeds. Similar results were reported by Afroz et al. [16], who observed that $8 \mathrm{~kg}$ of mustard increased the seed index. The experiment result showed the maximum plant height $(\mathrm{cm})$ was recorded at seed rate $5 \mathrm{~kg} \mathrm{ha}^{-1}$ whereas the minimum plant height $\mathrm{cm}$ observed at seed rate $5 \mathrm{~kg} \mathrm{ha}^{-1}$. In varieties the maximum height of plant was noted in Ho-1 and minimum plant height was observed in genotype hysun-38. The interaction results showed the maximum plant height was recorded at interaction of seed rate $5 \mathrm{~kg} \mathrm{ha}^{-1}$ $\mathrm{x}$ variety Ho-1, whereas minimum 
interaction result was observed at the seed rate $10 \mathrm{~kg} \mathrm{ha}^{-1} \mathrm{x}$ variety Hysun-38. Similarly [15] checked the effect of seeding rate on plant stand attributes quickly preceding harvest in sunflower. Head width did shift by seeding rate, with the most stretched out seed heads (5.9 inches) saw at the least seeding rate $(20,000$ plants section of land 1). The littlest head width (4.5 inches) was in the most thickly seeded plots $(32,000$ plants $\left.\mathrm{acre}^{-1}\right)$. The experiment results showed the maximum seed yield $\mathrm{kg} \mathrm{ha}^{-1}$ at seed rate $10 \mathrm{~kg} \mathrm{ha}^{-1}$ due to more plant population $\mathrm{m}^{2}$, whereas minimum seed yield $\mathrm{kg} \mathrm{ha}^{-1}$ were observed at seed rate $5 \mathrm{~kg} \mathrm{ha}^{-1}$. In varieties the maximum seed yield $\mathrm{kg} \mathrm{ha}^{-1}$ was recorded in variety $\mathrm{HO}-1$, whereas the minimum seed yield $\mathrm{kg} \mathrm{ha}^{-1}$ were observed in variety Hysun-38. The interaction results showed the maximum seed yield $\mathrm{kg} \mathrm{ha}^{-1}$ at interaction of seed rate $7.5 \mathrm{~kg} \mathrm{ha}^{-1} \mathrm{x}$ variety HO-1, whereas minimum interaction result of seed yield $\mathrm{kg} \mathrm{ha}^{-1}$ were observed at the seed rate $5 \mathrm{~kg} \mathrm{ha}^{-1} \mathrm{x}$ variety Hysun-38. Similarly [11] directed a test to explore the impacts of varieties and seed rates on yield and yield parts of sunflower reported that size and number of seeds were fundamentally influenced by seed rate. The result of experiment revealed that sunflower treated with three seed rates $(5,7.5$ and 10 $\mathrm{kg} \mathrm{ha}^{-1}$ ) among these seed rates highest plant population $\mathrm{m}^{2}$ were observed at the seed rate $10 \mathrm{~kg} \mathrm{ha}^{-1}$, taller plants were recorded at the seed rate $5 \mathrm{~kg} \mathrm{ha}^{-1}$, thick stem girth at the seed rate $5 \mathrm{~kg} \mathrm{ha}^{-1}$, maximum head diameter at the seed rate $5 \mathrm{~kg} \mathrm{ha}^{-1}$, greater seeds head 1 at the seed rate $5 \mathrm{~kg} \mathrm{ha}^{-1}$, higher seed weight head ${ }^{-1}$ at the seed rate $5 \mathrm{~kg} \mathrm{ha}^{-1}$, maximum seed index 1000 seed weight at the seed rate $5 \mathrm{~kg} \mathrm{ha}^{-1}$ and higher seed yield $\mathrm{kg} \mathrm{ha}^{-1}$ were recorded at the seed rate $10 \mathrm{~kg}$ $\mathrm{ha}^{-1}$. The result of experiment further revealed that three sunflower varieties (Ho1, NKS-278 and Hysun-38) among these varieties Ho-1 significantly recorded maximum plant population $\mathrm{m}^{2}$, taller plants, thick stem girth, higher head diameter, more seeds head ${ }^{-1}$, heavier seed weight head ${ }^{-1}$, bolder seed index 1000 seed weight and highest seed yield $\mathrm{kg} \mathrm{ha}^{-1}$ were recorded at the seed rate $10 \mathrm{~kg} \mathrm{ha}^{-1}$. Similarly [17] assessed the near execution of different sunflower hybrid varieties for yield and its associated qualities. Twelve sunflower cross breeds, i.e. G-101 (H1), DK-4040 (H2), SF187 (H3), S-278 (H4), Hysun-33 (H5), FH37 (H6), Ausigold-61 (H7), Ausigold-62 (H8), FSS-50 (H9), NX-00989 (H10), NX00997 (H11) and XIYU-12 (H12) were incorporated into the trail. It was watched that Hysun-33 demonstrated more important plant stature $(148.47 \mathrm{~cm})$ and achene head ${ }^{-1}$ (682.70) than every single other cross breed, however if there should arise an occurrence of yield $\left(3891.0 \mathrm{~kg} \mathrm{ha}^{-1}\right)$ and other related characteristics, for example, number of plants $\mathrm{m}^{-2}$, leaf territory list, head distance across and 1000-achene weight of SF-187 showed better execution by recording qualities (6.87), (4.33), (18.62) and (49.11g), individually, taking after Hysun-33 for a large portion of the attributes. From the outcomes it is inferred that the half and halves SF-187 and Hysun-33 demonstrated high profitability and are best adjusted to the climatic states of Faisalabad.

\section{Conclusion}

It is concluded that growth and yield parameters of sunflower was significantly affected by seed rate that sunflower crop production increased with the increasing of seed rate. Sunflower variety Ho-1 gave the highest yield at the seed rate $10 \mathrm{~kg} \mathrm{ha}^{-1}$ whereas variety NKS-278 and Hysun-38 also gave the better yield at the seed rate 10 $\mathrm{kg} \mathrm{ha}^{-1}$.

\section{Authors' contributions}

Conceived and designed the experiments: GM Laghari \& HA Panhwar \& AA, Panhwar, Performed the experiments: HA Panhwar, JKr Soothar, MM Rajput, A Abro 
\& J Kumar, Analyzed the data: GM Laghari \& J Kumar, Contributed reagents/ materials/ analysis tools: GM Laghari \& J Kumar, Wrote the paper: AA Kaleri \& MK Soothar.

\section{References}

1. Leland EF (1996). Salinity effect on four sunflower hybrids. Agron J 88: 215-219.

2. Rathore VS, Gautam RC \& Kaushik SK (2001). Yield, quality and nutrient uptake by sunflower as influenced by weed and nutrient management. J Ann Agric Res 22(3): 443-444.

3. Hussain TI \& Ahmed MA (2000). EM Technology a new looks for IPNM. In: Proc. Symp., Integrated Plant Nutrient Management, NFDC, Islamabad, Pakistan.

4. GOP (2014). Economic Survey of Pakistan, 2013-2014. Sunflower: Government of Pakistan, Ministry of Food, Agriculture and Livestock, Agric, \& Livestock Division (Economic Wing), Islamabad.

5. Vijayalakshmi K, Sanghi NK, Pelton W L \& Anderson CH (1975). Effects of plant population and row spacing on sunflower agronomy. Can J Pl Sci 55(2): 491-499.

6. Khan IA, Zubair \& Malik BA (1988). Various seed rates affect yield and yield components in mash. Pak J Agric Res 9(2): 165-167.

7. El-Naim AM \& Ahmed MF (2010). Effect of Irrigation Intervals and Interrow Spacing on Yield, Yields Components and Water Use Efficiency of Sunflower (Helianthus annuus L). J App Sci Res 6 (9): 1446-1451.

8. Vahedi B, Gholipouri A \& Sedghi M (2010). Effect of planting pattern on radiation use efficiency yield and yield components of sunflower. Rec Res Sci Tech 2(2): 38-41.

9. Jefferson T (2010). Sunflower: A native oilseed with growing markets. Production
Technology for sunflower: Thomas Jefferson Agric Ins Col 1-7.

10. Khalifa FM (2009). Effect of spacing on growth and yield of sunflower (Helianthus annuus L.) under two systems of dry farming in Sudan. $J$ Agric Sci 103(1): 213-222.

11. Ali A, Afzal M, Rasool IJ, Hussain S \& Ahmad M (2011). Sunflower (Helianthus annuus L.) hybrids performance at different plant spacing under agro-ecological conditions of Sargodha, Pakistan. Proc Int Conf on Food Eng and Biotech Singapore 9: 317322.

12. Darby H, Halteman $P$, Cummings $E$, Gervais A \& Madd R (2011). Sunflower Seeding Rate $x$ Nitrogen Rate Trial Report. Vermont University of Extension (USA): 1-7.

13. PARC (2011). Sunflower production technology: Pakistan Agricultural Research Council, Islamabad. p.1-6.

14. Darby H, Harwood H, Cummings E, Madden R, Monahan S \& Gervais A (2012). Seeding Rate x Nitrogen Rate Trial Ext Cr Soil Techni 1-9.

15. Johnson BL, Zarnstorff ME \& Miller JF (2010). Effect of Row Spacing and Plant Population on Oil Seed Sunflower. Proceedings of $21^{\text {st }}$ Sunflower Research Workshop Dgs 183-192.

16. Afroz MM, Sarkar MAR, Bhuiya MSU \& Roy AK (2011). Effect of sowing date and seed rate on yield performance of two mustard varieties. $J$ Bangladesh Agril Univ 9(1): 5-8.

17. Sarwar MA, Khalil-ur-Rehman MN, Javeed HMR, Ahmad W, Shehzad MA, Iqbal S \& Abbas HT (2013). Comparative performance of various sunflower hybrids for yield and its related attributes. Cer Agron Moldova (4): 57-64. 